\title{
Women in the LTTE: Birds of Freedom or Cogs in the Wheel?
}

\author{
Peng Wang \\ School of law, King's College London \\ London WC2R 2LS, England, United Kingdom \\ E-mail: peng.p.wang@kcl.ac.uk
}

\begin{abstract}
The Liberation Tigers of Tamil Eelam (LTTE) is a preeminent separatist organization fighting for an independent and sovereign Tamil state in the northern and eastern regions of Sri Lanka. LTTE women's involvement in the leadership and fighting forces of the group has given rise to fierce debates about whether the visibility of females in the LTTE fighting forces represented the 'true' liberation of the Tamil women and whether women would enjoy equal rights in the public during the post-conflict period. Actually, the Tamil Eelam is the overarching goal of the LTTE, and the emancipation of women has always been a secondary issue dependent on the liberation struggle. All the existing literature illustrates that the LTTE has been unsuccessful in creating the gender equality within the movement, and suggests that women have the right to achieve their emancipation and empowerment without linking to interests of the nationalist and ethnic struggles.
\end{abstract}

Keywords: Liberation Tigers of Tamil Eelam (LTTE), Women combatants, Female emancipation

\section{Introduction}

In the past several hundred years, Sri Lanka suffered a great deal: the two hundred years (more or less) Portuguese and Dutch colonial rule, then the 146 years British colonization, the sixty years of nationalist struggle, and subsequently the 50 years of ethnic cleansing, and within that twenty-five-year-old civil war (Sivanandan, 2010). On Sunday, 17 May 2009, the president of the Sri Lanka government declared the state's victory over the Liberation Tigers of Tamil Eelam (LTTE or Tamil Tigers) (Times Online, 2009). Prabhakaran, the leader of the LTTE, was subsequently killed by Sri Lanka Government forces on 19 May 2009 (Jeyaraj, 2009). The twenty-five years of civil war in Sri Lanka has attracted great attention from all over the world, and therefore an in-depth understanding of the conflict as well as its unique features remains a critical need in order to prevent the future of more insurgency (Grant, 2009).

The Liberation Tigers of Tamil Eelam (LTTE) is a preeminent separatist organization fighting for an independent and sovereign Tamil state in the northern and eastern regions of Sri Lanka (Rao, 1988; Wilson, 1988; Robert 1992; Joshi, 1995; Rajasingham-Senanayake, 2000; Gunaratna, 1998, 2002; Imtiyaz, 2008). The utilization of children as soldiers (Gray \& Matchin III, 2008), the assassinations of several high-ranking Indian and Sri Lanka politicians (Stack-O'Connor, 2007), as well as women's involvement as a significant tactical weapon (De Mel, 2004), can be defined as the fundamental characteristics of the LTTE. In this case, the complexity of LTTE can be discribed as 'the world's most intractable' (Nadarajah \& Sriskandarajah, 2005: 87) and 'the most dangerous and deadliest terrorist group in the world and certainly the most violent guerrilla organization of South Asian' (Van de Voorde, 2005: 185).

Traditionally males have been perceived as the agents of war, while females have always been portrayed as victims or refugees (Nordstrom, 1997). However, the mass utilization of female combatants in Sri Lanka by the Tamil Tigers has presented a great challenge to traditionalist ideas about gender roles in political violence and peace-building (Alison, 2004). This article challenges the idea that women are innately more peaceful and less physically aggressive than men through an examination of the roles of female combatants within the LTTE movement. The article first outlines the context of the civil war in Sri Lanka and the historical development of female combatants in the movement; then examines why the LTTE changed the policy to involve women in fighting roles, and the motivations why a large sum of women chose to participate in this organization. It, then, critically assesses the extent of female emancipation stemming from their participation within the movement, and the potential limitations of the empowerment for females. In the conclusion part, it presents that the LTTE has been unsuccessful in creating the gender equality, and suggests that women have the right to achieve their emancipation and empowerment without involving themselves in armed violence.

\section{Synopsis of the Sri Lanka Conflict}

The ethnic discrimination against the Tamil minority could be identified as the fundamental reason for the beginning of their anti-state movement. It could be significant to fully understand the roots, development and consequences of the conflict in order to critically assess the female emancipation in the twenty-five-year old civil war.

\subsection{The Brief History of the Conflict}

Sri Lanka (named Ceylon until 1972) gained independence from the British rule on $4^{\text {th }}$ February, 1948. The 
population of the Sri Lanka is approximately 21 million people. It is estimated that about 74 per cent of the population are Sinhalese, 12 per cent are Sri Lankan Tamil, 8 per cent are Muslim, and about 5 per cent are Indian Tamil and some small minorities, such as Burghers (Eurasians, mostly descended from Portuguese and Dutch colonizers; ), Malays and others (Samuel, 2001: 185; Alison, 2003: 38, Naik, 2008: 8). The Sinhalese are traditionally Buddhist, with a small percent of Christians. The Tamils, on the other hand, are predominately Hindu, also includes a Christian minority. The prolonged civil war in Sri Lanka is between two primary ethnic groups occupying the island: the primarily Buddhist Sinhalese in the south of the state and the primarily Hindu Tamils in the north and east of the country (Roberts, 1979, 1992; Laqueur, 1999; Morrison, 2001; Stack-O'Connor, 2007).

During British colonization of the Sri Lanka, the Tamils (especially Indian Tamils) are well-represented and given more education opportunities and better jobs than the Sinhalese (Sivanandan, 2010). After Sri Lanka got its independent, the Sinhalese-dominated government carried out a list of policies about cultural nationalism, and discriminated against the Tamil community in order to systematically improve their political, economic and educational position (Schrijvers, 1999). The discriminatory policies of the Sri Lanka Government can be listed in the following:

$>$ Disenfranchising the Indian Tamils. The Indian Tamils ('plantation Tamils') lost their citizenship rights immediately after the independent of Sri Lanka in 1948, and therefore the Sinhalese established their electoral majority in the whole country (Sivanandan, 2010).

Large irrigation-cum-colonization scheme. The large colonization schemes settled poor Sinhalese from the south in the primarily Tamil area, which changed the ethnic demography of the north-east area and also seriously influenced Sinhalese Tamil relations because this scheme brought in ethnic elements and ethnic tension (Wilson, 1974; Van Brabant, 1998).

$>$ Linguistic nationalism. Sinhala, the language of Sinhalese, was made the official language in 1957. This policy deeply offended the Tamils and led to many social problems in Tamil community, such as economic hardship, unemployment (Schrijvers, 1999; Sivanandan, 2010).

Ethnic policy of religion. Buddhism subsequently gained its 'rightful place'-state religion, which had 'struck at the heart of Tamil livelihood and achievement' (Sivanandan, 2010: 61).

$>$ Educational disruption and restriction. The Tamils' opportunities of getting access to higher education have been effectively discriminated by the government because of the policy of 'standardization' (Alison, 2003).

$>$ Police violence. Tamil leaders undertook mass non-violence demonstrations in order to protest Sri Lanka government, but surprisingly met with police violence (Sivanandan, 2010).

It seems that the Tamils had no choice but to take up arms against the Sinhalese cultural nationalism, just as Sivanandan (2010) arguing: 'the violence of the violated is never a matter of choice, but a symptom of choicelessness-and often it is a violence that takes on a life of its own and becomes distorted and self-defeating' ( $p$. 63). The widespread discrimination has driven the Tamil minority to violently protest the ethnic separation and nationalism of Sinhalese majority. Liberation Tigers of Tamil Eelam, or LTTE, under the direction of Velupillai Prabhakaran, was established on 5 May 1976 (Hoffman, 2006) and obtained its hegemony in the Tamil community through defeating other Tamil guerrilla groups in mid-1980s (Hudson, 2000). The LTTE, a high-profile military and political spearhead with fundamental 'aggression-hate-fanaticism' (Whittaker, 2001: 85), has fought relentlessly for almost 33 years for political independence of the Tamils.

The outbreak of the Sri Lanka civil war between the Sinhalese majority and the Tamil minority can be traceable to the major attack carried by the LTTE (which resulted in the deaths of 13 Sri Lanka soldiers) and subsequently Sinhalese 'Black-July' riots against the Tamil community in the year 1983. From then a series of attacks and counterattacks continued to become even more sophisticated: the first major attack conducted by the LTTE followed by anti-Tamil riots across Sri Lanka followed by numerous Tamil youth joining Tamil militant groups followed by the outbreak of the first Sri Lanka civil War followed by 'Indian Peace Keeping Force' Period followed by 1995 ceasefire and 2002 ceasefire, and finally the LTTE was defeated by the State in May 2009 (Hennayake, 1989; Joshi, 1995; Stokke \& Ryntveit, 2000; Naik, 2008). Since 1983, the civil war has resulted in over 70,000 deaths, and produced hundreds of thousands of refugees and so-called 'internal displaced people' (Van Brabant, 1998; The Economist, 2008).

\subsection{Background to Women's involvement}

Although women's military participation and their frequently involvement as suicide bombers could be identified as one of significant features of the LTTE, their involvements as combatants was not widespread until mid-1980s. Initially, women in the LTTE, who were referred to as 'birds of freedom', played an important role in the supporting services, such as propaganda, recruitment, information collection, medical care and fundraising (Maunaguru, 1995; 
Alison, 2004). The number of male cadres, however, had been significantly reduced in the early 1980s because of 'Indian Peace Keeping Force' (IPKF) occupation as well as a large number of Tamils left their country. Therefore, women were strongly recommended to participate as combatants in the Tamil movement in order to make up manpower shortage; and they were provided with systematic military training-weapon technology, suicide bombing, combat, for instance (Ann, 1993; Bouta, 2005). In 1983, the Vituthalai Pulikal Munani (Women's Front of the Liberation Tigers) was founded for women by the LTTE (De Mel, 2004). The Vituthalai Pulikal Munani began its first training for combat in Tamil Nadu (Indian) in 1985 and its first battle in July 1986 against Sri Lanka military (Ann, 1993). Women, under the direction of a male commander, successfully conducted the group's first suicide attack on Sri Lanka forces in 1987 (the fist suicide bombing led to over 100 deaths of Sri Lanka soldiers) (Stack-O'Connor, 2007). In 1989, the leadership structure of 'Women's Front of the Liberation Tigers' was set up by the LTTE leader Velupillai Prabhakaran (Ann, 1993).

Due to the LTTE begun its female-recruitment very recently, the proportionate of female combatants was very small until 1990. But the statistics for women participation in the LTTE suggest that proportion of women fighters within the LTTE increased dramatically, and truly justify the fundamental role of females in military activities and suicide missions (Alison, 2003, 2004; Bouta, 2005; ). The number of female soldiers composed around one-third of the LTTE core combat strength and they were 'inducted in all units of the movement including its naval force (the Sea Tigers), and its suicide squad; an elite force known as the Black Tigers' (Jordan \& Denov, 2007: 46). Moreover, the number of suicide activities carried out by female combatants comprised about $30 \%$ to $40 \%$ of the whole suicide missions (Schweitzer, 2002). Ann (1989) presents that LTTE female soldiers have been portrayed as 'the most fierce, extremely disciplined and courageous women combatants in the world' (p. 9). Mr Velupillai Prabhakaran, the creator of the women's military wing of the Liberation Tigers, emphasized that the participation of women in the Eelam war played a positive role and can be considered as the great achievement in this anti-state movement (De Mel, 2001).

\section{Why Women Soldiers in Sri Lanka?}

Some works (e.g. Enloe, 2000; De Mel, 2003; Jordan \& Denov, 2007) suggest that a large number of female LTTE soldiers made autonomous rational choice of engaging in "non-traditional gender roles and experiences, which represents a drastic change in the expected behavior of Tamil women, and a disruption in conventional gender constructions' (Jordan \& Denov, 2007:56). There are many scholars throughout the international community who are interested in answering questions: Why would the LTTE, an armed group embracing the traditional Tamil culture, want to create the 'Freedom Birds' to involve women in fighting forces? Why are women and girls willing to become members of LTTE and carry out attacks, particularly suicide attacks? These are two questions this part seeks to answer.

\subsection{Motivations of the LTTE to Create the Freedom Birds}

Women are conceptualized as subordinates to men according to the conventional roles and culture of the Tamil community (Schrijvers, 1999). The female tend to be under the protection/control of her father and brother during her childhood, and subsequently under the husband's control, and then remain under the control of her son if she lost her husband (De Mel, 2003; Sornarajah, 2004). Women should be self-sacrificing, chaste, reserve virgins until marriage, and hold strictly chaste and faithful for their legal husbands. Until 1980s, females were renowned as 'brave mother' because they were encouraged to hand their husbands and children over to the LTTE for the well-being of the nation. However, the most ruthless and longest Sri Lanka civil war urged the Tamil leader to change their policies towards women. Women in the movements had been carefully indoctrinated by the LTTE to take arms as 'women warriors' and gradually became an essential part of the anti-state force. There were complicated reasons: (1) a strategy need for more fighters, (2) women's tactical advantages against the Government of Sri Lanka (GOSL), (3) the need in the intra-Tamil competition; all of these offered the initiatives for the LTTE to change the policy towards women involvement.

\section{A. A Strategy Need for More Fighters}

The primary factor to understand 'why the LTTE use women' is that the number of male fighters decreased significantly during the early 1980s (Schrijvers, 1999). The LTTE reported the organization lost 860 male soldiers (about $8 \%$ of the whole members) between 1982 and 1987. It seems impossible for the Liberation Tigers to use roughly 4,500 cadres to response to Sri Lanka military and 30,000 Indian Peacekeeping forces (Stack-O'Connor, 2007). Moreover, Tamil males between the ages of fourteen and forty years were specifically targeted for detention, torture, execution and interrogation by the Sri Lanka security forces (Somasundaram, 2002; Stack-O'Connor, 2007). A great number of Tamils were not able to bear such inhuman treatment and decided to leave their country. The counterinsurgency policy of the GOSL succeeded in both decreasing the power of the Liberation Tigers and making them extremely difficult to conduct operations. Women, on the other hand, were not under the control of the Sri Lanka government and also in relatively large supply (Stack-O'Connor, 2007). 


\section{B. Women's Tactical Advantages against the GOSL}

Women, according to the traditional discourse, were inherently less violent and more peaceful than men. The rationale for employing female suicide bombers was 'the use of harmless-looking female members posing as pregnant women to circumvent extreme security measures and safely approach their targets' (Van de Voorde, 2005: 186). Men were forbidden to touch women in Sri Lanka culture; and there were not enough female staffs in the checkpoint, as a result, this situation left the GOSL with the dilemma toady: 'risk the anger of the population by touching women or risk the danger of attacks by letting women go unchecked' (Stack-O'Connor, 2007: 56). Women's tactical advantages (e.g. ability to evade security and much easier to get access to politicians) could be identified as an important factor for Mr. Prabhakaran to break the conventional ideology to create the 'Freedom Birds'.

\section{The Need in the Intra-Tamil Competition}

The value of the women or female emancipation is a key factor in the intra-Tamil completion for legitimacy (Stack-O'Connor, 2007). During 1980s, there were around 20 Tamil insurgent groups (among them, the LTTE, the Tamil Eelam Liberation Organization, the Eelam Revolutionary Organization of Students, the Eelam People's Revolutionary Liberation Front and the People's Liberation Organization of Tamil Eelam are the major ones), and many of them intended to be the sole representative of the Tamil society (O'Ballance, 1989; Wilson, 2000). The Liberation Tigers had to gain the broadest support against other Tamil militant groups as well as the GOSL by offering women a version of future-freedom, equality and happiness. Women's involvement encouraged the Tamil community to regard the Liberation Tigers as the most intelligent organization which was fully representative of the Tamil nation. Moreover, the creation of the Freedom Birds could help the LTTE gain the media benefit. Media coverage of the LTTE female suicide attacks brought much more criticisms about human rights issues of the GOSL rather than their acts of violence (Stack-O'Connor, 2007).

Moreover, women's desire to participate in the LTTE is another important issue, which will be referred in the next section. The LTTE is recognized as an extremely disciplined and the best organized terrorist organization, and it has adopted a series of methods to control the female combatants, such as separation of the sexes, the forbidden of pre-marital sexual relations, emphasis on loyalty and chastity for all members, the encouragement of intermarriage among its members, and dress policies (Jordan \& Denov, 2007; Stack-O'Connor, 2007). All these strict rules and regulations promote the LTTE to be an efficient and powerful military organization. However, the LTTE rules affect the female freedom and emancipation in a negative way. As Stack-O'Connor (2007) notes the Liberation Tigers 'makes women look and act like men without giving them the rights of men' (p. 51).

\subsection{Incentives of Female Combatants}

Maclure \& Denov (2006) suggests that an individual's choices to participate in armed rebel organization voluntarily cannot occur without the interaction with the broader social circumstances. The initial 'pull factor' about the change of the LTTE policy towards the active recruitment of women in the anti-state movement, seems to be primarily based on the strategic and tactical needs rather than on democratic commitment to equality and women's rights (De Silva, 1994; Maunaguru, 1995; Samarasinghe, 1996). However, there are a number of different and interesting 'push factors' that incite women to join the LTTE; some of them are identical to both men and women, others are estimated separately for women and men combatants.

\section{A. Tamil Nationalistic Beliefs}

Sumantra Bose (1994) argues that both men and women combatants are primarily motivated by Tamil nationalistic objectives. LTTE women, like the men, are essential part of the country and tend to participate in the conflicts to achieve a peaceful motherland. After interviewing many members or ex-members of the Liberation Tigers, Alison (2003) concludes that goals of independent Tamil nation, self-determination, freedom and human-rights could be regarded as the main motivations for them to join the civil war. In other words, the Tamils either keep silence on the widespread discriminations and live together in harmony with the Sinhalese majority, or fight against the autocratic government and create the freedom for the Tamil community.

\section{B. Rape and Fear of Sexual Assault}

Rape and fear of sexual violence seem to be the gender-specific motivations for females to take up arms. 'Women were systematically targeted for sexual violence during the past attacks and government invasion of Tamil community' (Jordan \& Denov, 2007: 53), as a result, their past experience as well as the need for protecting themselves from sexual assault played a major role in women's decisions to join the Liberation Tigers. Moreover, the previous sexual violence against the civilian women were cited as the evidence to make male soldiers strongly believe that violence against Sri Lanka government was the only way to obtain an independent Tamil nation (Stack-O’Connor, 2007). 
Chaste is a significant issue for Tamil women, women who are raped would be isolated by other Tamils. During the Indian intervention period, there were massive rapes and assaults committed by the Indian Peacekeeping Forces (Bose, 1994). As a consequence, hundreds of females since they were raped decided to be members of the LTTE and carried out vicious Freedom Birds suicide attacks rather than ending their life by themselves (Jorden \& Denov, 2007). On the other hand, the Liberation Tigers and other guerrilla groups appears more likely to use these notorious malconducts committed the Sri Lanka forces and the IPKF so as to recruit more and more women who angry with or fear of sexual violence (De Mel, 2001).

\section{The Deaths of loved ones and /or the Loss of Family Members}

Females in Tamil community made their decision to involve in the militant groups much easier if they noted their loved ones were killed by the Sri Lanka police or army (Alison, 2003; Jorden \& Denov, 2007). Female cadres sometimes were more violent and less sympathetic than male fighters, which partly or mainly because of their anger over the loss of family members at the hands of the Sri Lanka military (De Silva, 1995). Sita, the member of the LTTE, noted: 'my brother were killed and out of rage. It is unbearable for me to believe what was happening, so I joined the movement and wanted to die as my brother died' (Alison, 2003: 40).

\section{The Needs for Security}

The security needs for women includes the societal security of the ethno-national community, individual security and gender-specific security (Alison, 2004). Lacking an alternative meaningful life with their family members, losing their virgin because of sexual violence, the life of privation and misery because of the extreme depths of poverty, all of these resulted in the sense of desperation in Tamil women. The Tamil nationalism and the struggle for freedom had been transformed into a mass phenomenon; the Tamils were more likely to rely on the LTTE to protect themselves from violence, sexual assault and discriminations.

\section{E. The Spirit of Martyrdom}

The cult of martyrdom sometimes could be understood as 'the power of the bomb is link to the power of martyrdom' (Crenshaw, 2002: 9), which has been a central feature of the LTTE terrorism (Joshi, 2001; Schweitzer, 2002; Whittaker, 2002). De Voorde (2005) points out that 'the LTTE's suicide commandos perceive their self-sacrifice as a way of legitimizing their cause, inspiring imitation, and promising individual glory' (p. 188). Moreover, Gunawardena (2006) suggests that the self-sacrifice of the female bombers is 'almost an extension of the idea of motherhood in the Tamil culture' (p. 84). The research has realized that these suicide bombings appear to be rational choices made by these fighters-volunteer to die-to-kill (Perina, 2002). This outcome is contradictory with the idea conveyed by the mainstream media that there may be some psychiatric disorders or cognitive impairments that result in women's decisions to be suicide bombers.

\section{F. The Need for Female Liberation and Emancipation}

It has been suggested that many women who decided to join the Liberation tigers wanted to regard their participation as a good chance of breaking traditional Tamil cultural restrictions and obtaining female liberation (Bose, 1994). The adoption of the new self-concept and equal-gender relations as a result of their involvement in the movement can infuse them with a sense of pride and make them feel important for their motherland (Jorden \& Denov, 2007). Indeed, their participation in the nationalist movement not only can bring women advantages in future, but also can be considered as the only way for them to gain equality. According to Clara Beyler (2003),

There is a difference between men and women suicide attackers: women consider combat as a way to escape the predestined life that is expected of them. When women become human bombs, their intent is to make a statement not only in the name of a country, a religion, a leader, but also in the name of their gender. (p.3)

\section{Women in the LTTE: Birds of Freedom or Cogs in the Wheel?}

LTTE women's involvement in the leadership and fighting forces of the group has given rise to fierce debates among human right issues, academics, and female emancipation about whether the visibility of females in the LTTE fighting forces represented the 'true' liberation of the Tamil women and whether women would enjoy equal rights in the public during the post-conflict period (Stack-O'Connor, 2007). The LTTE, like other Tamil guerrilla groups, emphasized that their female fighters were 'the supreme symbol of women liberation' within their commitment to national liberation movements (Alison, 2003: 44). One of the most important aims of the establishment of the Women's Front of the LTTE (the Freedom Birds) was creating the equal position for Tamil women in the society: eliminating all discrimination against women, protecting women from any sexual violence, and promoting women to control their own lives. Mr. Prabhakaran, the Tamil national leader, argued that the liberation of Tamil women was a child born out of the outbreak of LTTE's liberation struggle (ibid). Through participating in the Liberation Tigers, women may achieve great respect and admiration, freedom from the traditional lifestyle imposed on Tamil women, a sense of equality with other male soldiers, and a sense of pride and accomplishment due to their contributions to 
their motherland (Jordan and Denov, 2007).

Ann in her work titled 'Women Fighter's of Liberation Tigers' states that women as the freedom birds belong to 'a totally new world, a world outside a normal woman's life. And that is what makes these women fighters so interesting and admirable' (1993: ii). Bose (1994) maintains that women have been well represented in the military and political activities. Specially, women have involved in all kinds of missions, from support services to guerilla fighting to suicide bombing; and they have been distributed in almost all departments/sections of the organization, even in the LTTE's Central Committee (the top decision-making body of the LTTE). Moreover, he asserts that 'women constitute the most remarkable feature of our national struggle', and therefore the great contributing effect resulting from the changing status of women should not be underestimated (p. 109-111). To sum up, female emancipation was made possible through women's access to ground-breaking training, roles and responsibilities, and in return the involvement of women was a great push factor for the Tamil movement.

However, the reality is quite different: the term 'Freedom Birds' in the context of nationalistic conflicts primarily emphasized on the political and propaganda functions rather than the empowerment of women, thus women's liberation has always been subordinate to the liberation struggle of Tamil nation (Alison, 2003; Gunawardena, 2006). Schrijvers (1999) suggests that the ideal lifestyle of the Tamil women in the earlier period was the celebration of life, which included the enjoyment of freedom, equality, prosperity and sexuality, as well as the love of the music and the arts. The LTTE, however, indoctrinated the Tamil civilians with the ideas of abstinency, self-sacrifice, martyrdom and death. Similarly, Stack-O'Connor (2007) assesses the rules and regulations of the Liberation Tigers, and concludes that these extremely strict rules and controls make women become 'armed virgins' that they act like male fighters but without the rights of men. In addition, some researchers have made comments on Bose's argument ('women are well represented in the Liberation Tigers'). Alison (2003) presents that the political culture and ideology of the organization could be much more important than mere numbers of women. Jordan and Denov (2007) argues that 'the reproduction of ideological doctrines such as discipline and loyalty, as well as traditional customs, such as the moral restriction on pre-marital sexual relationships, and the need to request permission to leave the movement, are highly reminiscent of the traditional Tamil culture' (p. 58).

As Coomaraswamy (1996) maintains that LTTE female combatants actually become 'Cogs in the Wheel' rather than 'Birds of Freedom'. Women are implementers of the missions designed by others; they are soldiers, fighters and suicide bombers, but not planers, deciders or designers. Women, in contrast with traditional image, are more aggressive and frightening than male members, which could be an important feature in Tamil movement. As P. L. de Silva (1995) presents that women fighters in the LTTE have a fearsome reputation: 'female cadres have to be more tough, ruthless and less-sympathetic-in a word, more macho-in order to complete for status and recognition in a traditionally patriarchal context' (p. 184). Jordan and Denov note that it may be dramatically difficult for female combatants to realize equality within the movement if women were facing strict gender-constructions as well as prevalent conventional culture standards (2007). It can be argued that the emancipation and empowerment of Tamil women is dependent on the involvement in armed forces controlled and dominated by the male authority. Moreover, women are expected to achieve 'total' empowerment only through 'relentless perseverance together with a long-term collective dedication' (Ann, 1989:11). However, the true liberation of women is that both men and women are created equal. Women should be independent, autonomous and self-directed without being 'linking to the interests of nationalists and ethnic struggle' (Schrijvers, 1999: 328).

The questions of the influence of the female combatants on Tamil society, and whether or not the rights obtained through women's active participant in the movement could autonomously translate into peacetime, are increasingly sophisticate to answer. Female combatants in the national liberation struggle view themselves the same as male fighters that they are fighting together against the enemy to protect the interests of their nation. However, although women take an active part in nationalist conflicts, there is 'a recurring global pattern of their postwar remarginalization and return to traditional roles' (Alison, 2004: 458; Jordan \& Denov, 2007: 59). The research about other liberation movements also presents that women are reintegrated into the society through being conferred the conventional roles (Samarasingle, 1996). Jamayaha (2004) notes that female ex-combatants in the peacetime have to give up independent and rights, and also they are politely required to go back into families and assigned more female roles. Wilford (1998) suggests that fighting alongside men to achieve an independent nation cannot guarantee female cadres' inclusion as equal citizens during times of peace. The complete failure of the Tamil movement has definitely brought the questions of women's right and remarginaliztion in a unified multi-ethnic country. The existing literature suggests that the Sri Lanka government is uncertain how to respond to the ex-members of 'Freedom Birds'. But one thing that I can make sure is that the agenda for women would change following the dramatic changes of political and military situations. Most of the discriminations against the Tamils (especially Tamil women), to some extent, will be unchanged within next few years because of the Sinhalese greatest anger against the extremely cruel and brutal violence by LTTE female cadres. What Tamil women can do is either keep 
silence and accept the reality, or take up arms again for creating their land of hopes and dreams.

\section{Conclusion}

The widespread influence of women in the LTTE may cause scholars, journalists and the public to overstate their importance to societal changes of the Sri Lankan Tamil. Despite the LTTE women seem to be more violent and aggressive in the liberation struggles than their male counterparts, women are still positioned within the 'victim' complex. Despite women's involvement might be an important 'push factor' for the creation of an independent Tamil, women remain a minority within the organization and the effect is limited. Despite female cadres obtain non-traditional rights through their participant in unconventional gender roles, whether their rights gained during the movement can automatically translate into times of peace is uncertain.

By examining why the LTTE decided to employ women and how it integrated women, as well as analyzing why Tamil women made decisions to take up arms, one conclusion can be made is that the decisions made by both the LTTE and Tamil women were their rational choices. However, the Tamil Eelam is the overarching goal of the LTTE, and the emancipation of women has always been a secondary issue dependent on the liberation struggle. Joke Schrijvers (1999: 328) notes that the form of the feminism is that 'women are defined in their own rights, without being linked to the interests of the nationalist and ethnic struggles'. According to Schrijvers' argument, the LTTE has not successfully provided the meaningful equality for women; the things that the LTTE has offered are the strict gender restrictions and reproductions of the conventional discourse. The empowerment and emancipation of women could not automatically be achieved by the victory of the movement. Moreover, the complete failure of the LTTE movement illustrates female combatants have to give up arms and lose their non-traditional rights, even freedom. Women fighters, used to be the heroine of the Tamil community, have once again become victims. (Word Count: 2216)

\section{References}

Ann, A. (1989). Women Fighters of Liberation Tigers. Jaffna: LTTE Publication Section.

Ann, A. (1993). Women Fighters of Liberation Tigers. Jaffna: LTTE Publication Section.

Alison, M. (2003). 'Cogs in the Wheel? Women in the Liberation Tigers of Tamil Eelam', Civil War, 6/1: 37-54.

Alison, M. (2004). 'Women as Agents of Political Violence: Gendering Security', Security Dialogue, 35/4:447-463.

Beyler, C. (2003). Messengers of Death: Female Suicide Bombers. Herzliya: ICT.

Bose, S. (1994). States, Nations, Sovereignty: Sri Lanka, India and the Tamil Eelam Movement. New Delhi: Sage Publications.

Bouta, T. (2005). Gender and Disarmament, Demobilization and Reintegration: Building Blocks for Dutch Policy. Clingendael Conflict Research Unit: Netherlands.

Coomaraswamy, R. (1996). 'Tiger Women and the Question of Women's Emancipation', Pravada, 4/9: 8-10.

Crenshaw, M. (2002). "'Suicide" terrorism in comparative perspective', in Anti-Defamation League, eds., Countering suicide terrorism, 21-29. New York: Anti-Defamation League.

Deegalle, M. (2006). Buddhism, Conflict and Violence in Modern Sri Lanka. London: Routledge.

De Mel, N. (2001). Women \& the Nation's Narrative: Gender and Nationalism in Twentieth Century Sri Lanka. Maryland: Rowman \& Littlefield Publishers, ING.

De Mel, N. (2002). 'The Cinematic Suicidal Body and its Politics: Review of Kalu Sudu Mal', in Robert Crusz, eds., Cinesith, 45-48. Colombo: Asian Film Center.

De Mel, N. (2003). 'Agent or Victim? The Sri Lankan Woman Militant in the Interregnum', in Wenona Giles, Malathi de Alwis, Edith Klein \& Neluka Silva, eds., Feminists under Fire: Exchanges across War Zones. Toronto: Between the Lines.

De Mel, N. (2004). 'Body Politics: (Re)Cognising the Female Suicide Bomber in Sri Lanka', Indian Journal of Gender Studies, 11/1: 75-93.

De Silva, M. (1994). 'Women in the LTTE: Liberation or Subjugation?', Pravada, 3/7: 28.

De Silva, P. L. (1995). 'The Efficacy of "Combat Mode": Organization, Political Violence, Affect and Cognition in the Case of the Liberation Tigers of Tamil Eelam', in Pradeep Jeganathan \& Qadri Ismail, eds., Unmaking the Nation: The Politics of Identity and History in Modern Sri Lanka, 176-190. Colombo: Social Scientists' Association.

Enloe, C. (2000). Maneuvers: The International Politics of Militarizing Women's Lives. Los Angeles: University of California Press.

Grant, P. (2009). Buddhism and Ethnic Conflict in Sri Lanka. NY: State University of New York Press. 
Gray, D. H. and Matchin III, T. O. (2008). 'Children: The New Face of Terrorism', International NGO Journal, 3/6: 108-114.

Gunaratna, R. (1998). 'International and regional security implications of the Sri Lankan Tamil insurgency'. Retrieved January 20, 2010, at http://www.ict.org.il.

Gunaratna, R. (2002). 'Suicide terrorism in Sri Lanka and India', in Anti-Defamation League, ed., Countering suicide terrorism, 101-108. New York: Anti-Defamation League.

Gunawardena, A. (2006). 'Female Black Tigers: A Different Breed of Cat?', Female Suicide Bombers: Dying for Equality. $\quad$ Retrived April 2010, at http://se1.isn.ch/serviceengine/Files/ISN/91154/ichaptersection_singledocument/4E1EFED5-5AC3-449D-A99B-46 66C2B29FF8/en/08_Female+Black+Tigers.pdf.

Hennayake, S. K. (1989). 'The Peace Accord and the Tamils in Sri Lanka', Asian Survey, 29/4: 401-415.

Hoffman, B. (2006). Inside Terrorism. New York: Columbia University Press.

Hudson, R. A. (2000). Who becomes a terrorist and why: The 1999 government report on profiling terrorists. Guilford, CT: The Lyons Press.

Imtiyaz, A. R. M. (2008). 'Ethnic Conflict in Sri Lanka: The dilemma of building a unitary state', India Intervention, $5,125-147$.

Javamaha, D. (2004). Partners in Arms: LTTE Women Fighters and the Changing Face of the Sri Lankan Civil War. Retrieved October $2^{\text {nd }}, 2009$, at www.jjay.cuny.edu/terrorism/womencombatants.pdf.

Jeyaraj, D. B. S. (2009). “ 'Operation KP': The dramatic capture and after”, The Hindu. Available at www.hindu.com/2009/08/09/stories/2009080952680900.htm.

Jordan, K. and Denov, M. (2007). 'Birds of Freedom? Perspectives on Female Emancipation and Sri Lanka's Liberation Tigers of Tamil Eelam', Journal of International Women's Studies, 9/1: 42-62.

Joshi, C. L. (2001). 'Sri Lanka: Suicide bombers', Far Eastern Economic Review, June, 64-66.

Joshi, M. (1995). 'On the razor's edge: The Liberation Tigers of Tamil Eelam'. Studies in Conflict and Terrorism, 19: $19-42$.

Keairns, Y. (2002). The Voices of Girl Child Soldiers. New York \& Geneva: Quaker United Nation Office.

Laqueur, W. (1999). The new terrorism: Fanaticism and the arms of mass destruction. New York: Oxford University Press.

Maclure, R. and Denov, M. (2006). 'I Didn't Want to Die So I Joined Them: Structuration and the Process of Becoming Boy Soldiers in Sierra Leone', Journal of Terrorism and Political Violence, 18/1: 119-135.

Maunaguru, S. (1995). 'Gendering Tamil Nationalism: The Construction of woman in Projects of Protest and Control', in Pradeep Jeganathan and Qadri Ismail, eds., Unmaking the Nation: The Politics of Identity and History in Modern Sri Lanka, 158-175. Colombo: Social Scientists’ Association.

Morrison, B. M. (2001). 'The transformation of Sri Lankan society, 1948-1999: The fragmentation of centralism', African and Asian Studies, 36/2: 181-202.

Nadarajah, S. and Sriskandarajah, D. (2005). 'Liberation struggle or Terrorism? The Politics of Naming the LTTE', Third World Quarterly, 26/1: 87-100.

Naik, A. (2008). 'Sarendib's Sorrow: Sri Lanka's Continuing Conflict', Socio-Legal Review, 4, 55-88.

Nordstrom, C. (1997). Girls and Warzones: Troubling Questions. Uppsala: Life and Peace Institute.

O’Ballance, E. (1989). The Cyanide War: Tamil Insurrection in Sri Lanka 1973-88. London: Brassey's.

Perina, K. (2002). 'Suicide terrorism: Seeking motives beyond mental illness', Psychology Today, 35: 15-24.

Pirapaharan, V. (1993). 'Tamil National Leader Hon. V. Pirapaharan's Women’s International Day Message'. Eelam Web, Available from www.eelamweb.com/leader/messages/women/1993/.

Rajasingham-Senanayake, D. (2000). 'Democracy and the problem of representation: The making of bi-polar ethnic identity in post-colonial Sri Lanka', in A. Nandy, J. Pfaff-Czarnecka, E. T. Gomez, \& D. Rajasingham-Senanayake, eds., Ethnic futures: The state and identity politics in Asia, 99-134. Thousand Oaks, CA: Sage.

Rao, P. V. (1988). 'Ethnic Conflict in Sri Lanka: India's Role and Perception', Asian Survey, 28/4: 419-436.

Roberts, M. (1979). Collective identities, nationalism and protest in modern Sri Lanka. Colombo, Sri Lanka: Marga Institute.

Roberts, M. (1992). 'Nationalism, the past and the present: The case of Sri Lanka', Ethnic and Racial Studies, 16: 
133-166.

Samarasingle, V. (1996). 'Soldiers, Housewives and Peace Makers: Ethnic Conflict and Gender in Sri Lanka', Ethnic Studies Report, 14/2: 213.

Samuel, K. (2001). 'Gender Difference in Conflict Resolution: The Case of Sri Lanka', in Inger Skjelsbaek and Dan Smith, eds., Gender, Peace and Conflict, 184-204. London: Sage.

Schrijvers, J. (1999). 'Fighters, Victims and Survivors: Constructions of Ethnicity, Gender and Refugeeness among Tamil in Sri Lanka', Journal of Refugee Studies, 12/3: 307-333.

Schweitzer, Y. (2002). 'Suicide terrorism: Development and main characteristics', in Anti-Defamation League, eds., Countering suicide terrorism, 77-88. New York: Anti-Defamation League.

Sivanandan, A. (2010). 'The cleansing in Sri Lanka', Race \& Class, 51/3: 59-65.

Somasundaram, D. (2002). 'Child Soldiers: Understanding the Context', British Medical Journal, 324, 1268-1271.

Sornarajajah, N. (2004). The Experience of Tamil Women: Nationalism, Construction of Gender, and Women's Political Agency, Lines. October 2009, at www.lines-magazine.org/Art_May 04/nanthinil.htm.

Stack-O'Connor, A. (2007). 'Lions, Tigers, and Freedom Birds: How and Why the Liberation Tigers of Tamil Eelam Empolys Women', Terrorism and Political Violence, 19: 43-63.

Stokke, K. and Ryntveit, A. K. (2000). 'The Struggle for Tamil Eelam in Sri Lanka', A Journal of Urban and Regional Policy, 31/2: 285-304.

The Economist (2008). 'Sri Lanka: Not Much to Celebrate', The Economist, available at www.economist.com/world/asia/displaystory.cfm?story_id=10656855.

Times Online (2009). 'President to announce end of war'. Times Online, available at www.sundaytimes.il/090517/News/sundaytimesnews_01.html.

Trawick, M. (1996). 'Gendered Aspects of International LTTE Image-Formation', Paper for the Conference on Violence against Women in South Asia, ICES, Colombo 27-31 March 1996 (Unpublished).

Van Brabant, K. (1998). 'Sri Lanka', in Hampton, J. eds., Internally Displaced People: A Global Survey, 148--153. London: Earthscan.

Van de Voorde, C. (2005). 'Sri Lankan terrorism: Assessing and responding to the threats of the Liberation Tigers of Tamil Eelam (LTTE)', Police Practice and Research, 6/2: 181-199.

Van Der Weyden, M. B. (2008). ‘Teaching Tamil Tigers', Medical Journal of Australia, 188/9: 544-545.

Van Hear, N. (1998). 'Editorial Introduction to the Special Issue of Refugee Studies and the Refugee Regime in Transition', Journal of Refugee Studies, 11/4: 341-349.

Walker, R. (2010). 'Violence, the everyday and the question of the ordinary', Contemporary South Asia, 18/1: 9-24.

Whitehall, J. S. (2007). 'Teaching Tamil Tigers', Med J Aust, 187: 703-705.

Whittaker, D. J. (2001). The terrorism reader. New York: Routledge.

Whittaker, D. J. (2002). Terrorism: Understanding the global threat. London: Longman/Pearson.

Wilford, R. (1998). 'Women, Ethnicity and Nationalism: Surveying the Ground', in Rick Wildford \& Robert L. Miller, eds., Women, Ethnicity and Nationalism: The Politics of Transition, 1-22. London: Routledge.

Wilson, A. J. (1974). Politics in Sri Lanka 1947-1973. London and Basingstoke: Macmillan.

Wilson, A. J. (1988). The break-up of Sri Lanka: The Sinhala Tamil conflict. Honolulu: University of Hawaii Press.

Wilson, A. J. (2000). Sri Lankan Tamil Nationalism: Its Origins and Development in the Nineteenth and Twentieth Centuries. University of British Columbia Press. 